\title{
Verification of the dependence of factors determining the market value of residential real estate at the stages of the life cycle
}

\author{
Irina Saenko ${ }^{1}$, Ekaterina Kushina ${ }^{1}$, and Valeria Pukhova $^{1, *}$ \\ ${ }^{1}$ Siberian Federal University, 660041, Svobodnyi avenue, 79, Krasnoyarsk, Russia
}

\begin{abstract}
The paper reflects the results of the study of the dependence of factors that form the market value of residential real estate objects at the stages of life cycle on the example of the residential real estate market in the city of Krasnoyarsk. It was determined that the location and lifetime of facilities are the key factors in the formation of the market value of residential property. Based on the conducted economic and statistical analysis, it is proved that the importance of the residential object location can suppress the influence of a high degree of depreciation of the building, thereby increasing the market value of residential property in it. It is justified in the work that the value of a location, being a qualitative characteristic of residential real estate, involves the development of quantitative approaches to its measuring and valuating in order to solve theoretical and methodological problems of management and development of housing construction.
\end{abstract}

\section{Introduction}

Identification of the key factors that impact formation of the market value of these objects, taking into account the stage of the life cycle, is one of the main issues of modern valuation of residential real estate and the development of investment projects in housing construction. Determination of these factors, the study of their interrelationships with the market value, makes it possible to obtain an effective tool for estimating and forecasting the value of residential real estate objects, and to determine the economic efficiency of selecting particular building options.

To determine more accurate and up-to-date information about the market value of residential real estate objects, it is necessary to identify the main factors affecting the cost at certain stages of the life cycle. The existing system of management and valuation of residential real estate objects does not adequately respond to rather significant questions: what factors and to what extent have the greatest impact at the stages of the life cycle, what is the relationship between the influence of these factors and the cost. In addition, the relevance of the study of market mechanisms and factors determining the cost of housing is also defined by the changes in the legislation, referring to the Tax Code of the Russian Federation, on the transition from the land tax and personal property tax to a single property

*Corresponding author: vvvetrova@ya.ru 
tax: the tax base now is the cadastral value of the property at the date of setting such an object of taxation for the cadastral registration and not the inventory value.

Determining the factors shaping the value of residential real estate and identification of the nature of their interaction will create a reliable theoretical basis for individual and mass valuation of objects when concluding transactions for sale and purchase of real estate on the housing market, and when calculating the taxable base of residential real estate.

In this regard, the study, which was aimed at developing a model for the dependence of the market value and the life cycle of residential real estate objects on the basis of the allocation and evaluation of the key factors that affect the formation and determination of value by the stages of the life cycle, supplements existing scientific and practical developments in this thematic area.

\section{Literature review}

We believe that the market value of a residential property is the most likely price that would suit the participants in a deal with a residential property in the competitive and open market environment, subject to all the conditions necessary to enter into an honest transaction, provided that a buyer and a seller act wisely and in the informed way, considering that the cost is not exerted undue influence and it is formed on the basis of objectively significant factors affecting it.

The scientific publications of a number of domestic and foreign authors (I.N. Anisimova, N.P. Barinov, S.V. Gribovskyi [1], A.V. Peshkov [2], T.V. Fedyunina, I.S. Krasnov [3], S.V. Gribovskyi [4], M.V. Shtan [5], N.V. Rodionova [6], L.V. Lyutova, O.I. Pyatkovskyi [7], E.S. Ozerov [8], S.G. Stelma [9], V.V. Buzirev [10], O.S. Gaydayichuk [11], T.I. Morozova [12], T.V. Shcherbakova [13], V.M. Balkin [14], V.L. Yasnitskyi [15], Chengxiang Zhuge, Chunfu Shao, Jian Gao, Chunjiao Dong, Hui Zhang [16], Iván García-Magariño, Raquel Lacuestaa [17], Borst R.A. [18], Hanna Augustyniak, Krzysztof Olszewski, Joanna Waszczuk, Jacek Łaszek [19], Chris Brooks [20], Vahida Zujoa, Diana Car-Pusicb, Valentina Zileska-Pancovskac [21], Pu Gong, Dong Zou, Jiayue Wang [22]) are devoted to the study of the influence of certain factors on the formation of the market value of residential real estate objects. However, presently, the questions of determining the dependence of the life cycle and market value are given too little attention in the available works. This question has not been practically studied.

The valuation of the market value of residential real estate is carried out at all stages of the life cycle of the building, which acts as their physical basis for the existence, and is a result of the investment and construction activities, forming, together with the surrounding environment, the consumer characteristics of the facilities. At the same time, it should be noted that the purpose of valuation and the factors determining the market value of residential real estate objects throughout the life cycle are changing, as reflected in the Table 1. 
Table 1. The purpose of valuation and the factors of formation of the market value at the stages of the life cycle of residential real estate (compiled by the authors).

\begin{tabular}{|c|c|c|}
\hline $\begin{array}{l}\text { Stage of the life } \\
\text { cycle }\end{array}$ & $\begin{array}{l}\text { Purpose of } \\
\text { valuation }\end{array}$ & $\begin{array}{l}\text { Factors influencing the formation of the market } \\
\text { value }\end{array}$ \\
\hline $\begin{array}{ll}\text { Pre-design } \\
\text { design works }\end{array}$ and & $\begin{array}{l}\text { Verification of the } \\
\text { feasibility of } \\
\text { investments } \\
\text { (evaluation of the } \\
\text { effectiveness of the } \\
\text { project) }\end{array}$ & $\begin{array}{l}\text { Location and prestige of the district (location in the } \\
\text { settlement plan and surrounding environment; } \\
\text { proximity to the business center, places of } \\
\text { employment, residential areas, roads, railways, } \\
\text { coast, green areas, communal facilities; accessibility } \\
\text { and condition of engineering communications; } \\
\text { availability of social and cultural facilities; } \\
\text { accessibility of public transport; environmental } \\
\text { situation). }\end{array}$ \\
\hline Construction & $\begin{array}{l}\text { Evaluation of rights } \\
\text { to real estate in } \\
\text { transactions of } \\
\text { purchase and sale on } \\
\text { the primary housing } \\
\text { market, } \\
\text { determination of the } \\
\text { taxable base }\end{array}$ & $\begin{array}{l}\text { Location and prestige of the area; physical } \\
\text { characteristics of the building and living quarters } \\
\text { (architectural expressiveness of the building; } \\
\text { dimensions; architectural and planning and } \\
\text { volumetric-constructive solutions of living quarters; } \\
\text { engineering solutions of the life support systems; } \\
\text { availability of built-in premises in the building for } \\
\text { comfortable living); degree of object readiness }\end{array}$ \\
\hline Operation & $\begin{array}{l}\text { Valuation of } \\
\text { residential real } \\
\text { estate in transactions } \\
\text { on the secondary } \\
\text { housing market, } \\
\text { determination of the } \\
\text { taxable base }\end{array}$ & $\begin{array}{l}\text { Location and prestige of the area; physical } \\
\text { characteristics of the building and living quarters, } \\
\text { taking into account their actual state (the degree of } \\
\text { physical and functional wear and tear, depending on } \\
\text { the year of construction of the building, determining } \\
\text { the period of operation) }\end{array}$ \\
\hline Liquidation & $\begin{array}{l}\text { Estimation the cost } \\
\text { of disposal } \\
\text { (liquidation) of the } \\
\text { property, estimation } \\
\text { of the cost of } \\
\text { creating a similar } \\
\text { facility }\end{array}$ & $\begin{array}{l}\text { Location and prestige of the area; conditions of } \\
\text { structural elements of the building, taking into } \\
\text { account the degree of physical and functional wear } \\
\text { and tear, depending on the year of construction of the } \\
\text { building, determining the period of operation. }\end{array}$ \\
\hline
\end{tabular}

Thus, the location and prestige of the area are factors of formation of the market value of residential real estate objects throughout the life cycle of the building in which they are constructed. When constructing an object, one of the factors determining the market value is the degree of readiness of the facility, and the year of construction of the building is the important factor at the stage of operation and liquidation of an object. The physical characteristics of the building and living quarters, being a very important factor in the formation of the market value of residential real estate objects at the stage of construction and operation, do not participate in the formation of the market value of residential real estate objects at the stage of pre-design and design, as well as the liquidation of the object. In connection with the foregoing, as a scientific hypothesis, we assume that there is a linear dependence between the market value and the life cycle of residential real estate, and the main key factors determining and shaping the market value are the location (prestige of the area) and the year of construction (determining the degree of wear and cycle time) of the object. 


\section{Methods applied}

In order to prove the above assumptions and to search the relationship between the life cycle and the market value of residential real estate objects, the existing market trends on the residential real estate market of Krasnoyarsk were studied and analyzed as initial and necessary information for modelling. The correlation-regression analysis method was used to process an array of data from firms of real estate developers and real estate agencies for the purpose of determining the dependence of the cost of 1 square meter of residential property on the key factors: a differentiation coefficient was used to characterize the location, determined on the basis of urban planning value of land in Krasnoyarsk [23]; the factor of the life cycle of the building was tied to the year of commissioning the residential building (all other factors being equal). The data of more than 1500 objects of residential real estate in Krasnoyarsk for 2016 were collected and processed.

The Figure 1 shows the regression model of the market value of dependence of 1 sq. meter of housing on the location.

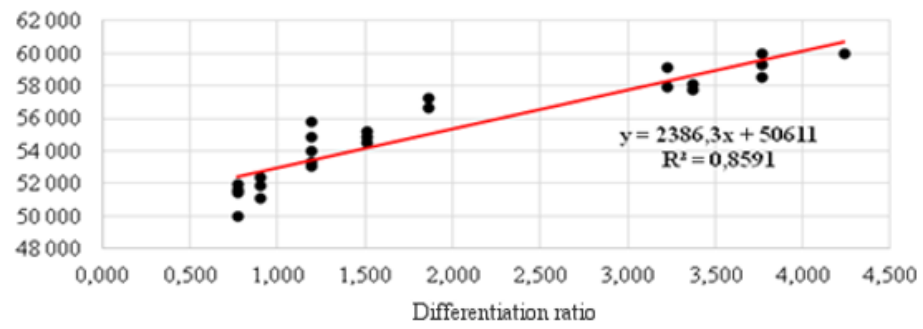

Fig. 1 The model of dependence of the market value of 1 square meter of housing on the location of the object.

Thus, an increase in the coefficient of differentiation, characterizing the consumer properties of the location of housing by 1 , contributes to the growth of the market value of 1 square meter of housing on 2386.3 rubles.

The Figure 2 shows the regression model of the dependence of the cost of 1 square meter of housing from the time of commissioning of a residential building.

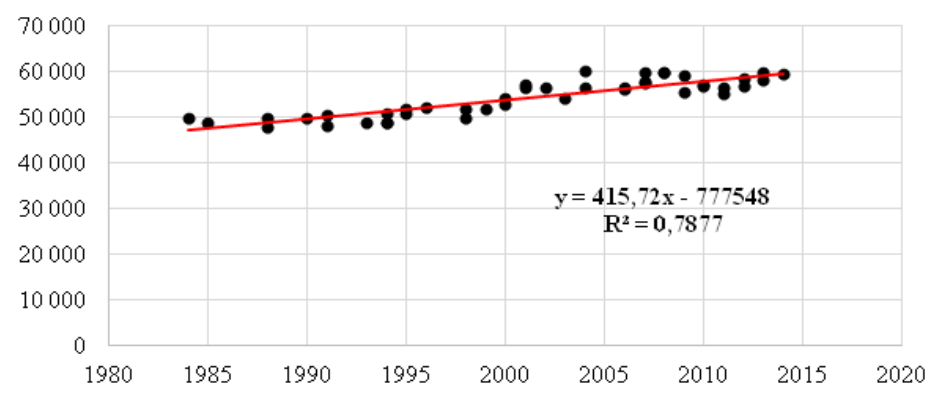

Fig. 2. The model of dependence of the market value of 1 square meter of housing on the year of commissioning of the residential building.

Thus, with an increase in the life of operation of the residential building, the market value of 1 square meter of the objects of residential real estate in it will decrease on 415.72 rubles.

In course of the study, a two-factor model of the dependence of the market value of housing on the location (X1) and the year of construction (X2) was obtained.

$$
\mathrm{Y}=3358.19 * \mathrm{X} 1+478.52 * \mathrm{X} 2-909253.28
$$


The constructed model has a coefficient of determination $\mathrm{R}^{2}=0.727$ and a correlation coefficient $\mathrm{R}=0.853$, which shows a close relationship between the identified factors location, a year of commissioning and effective indicator - the market value of 1 square meter of housing.

\section{Results}

Throughout the life cycle of a residential property, its market value is influenced by many factors. According to the results of the study, the key of them at each stage are the location and the year of commissioning the residential building that is verified in the obtained models of mathematical statistics. It should be noted that today there are no quantitative characteristics of the location value, and this factor is a qualitative characteristic. The resulting two-factor model reflects the greater importance of the location factor, in contrast to another key factor - the life of the facility, that confirmed our hypothesis that the value of the location of a residential property can suppress the influence of high degree wear of a building, thereby increasing the market value of residential properties in it.

\section{Summary and conclusions}

The value of the location of residential properties is the most significant factor in the formation of market value and, being a qualitative characteristic, involves the development of quantitative approaches to its measuring and valuating in order to solve theoretical and methodological problems of management and development of housing construction.

\section{References}

1. I. N. Anisimova, N. P. Barinov, S. V. Gribovskii, Evaluation Issues, 2 (2004)

2. A. V. Peshkov, Proceedings of the Irkutsk State Technical University, 11(58), 258-262 (2011)

3. T. V. Fedyunina, I. S. Krasnov, Bulletin of Science and Education Development, 3, 195-198 (2014)

4. S. V. Gribovskii, Evaluation Issues, 1, 2-10 (2002)

5. M. V. Shtan, Evaluation Questions, 4(86), 23-31 (2016)

6. N. V. Rodionova, Audit and Fin. Analysis, 2, 10-15 (2009)

7. L. Lyubov, O. I. Pyatkovsky, Proceedings of the Altai State Techical University, 1, 110113 (2014)

8. E. S. Ozerov, Formation of the system of management of profitable real estate (Publishing house Polytechnical University, St. Petersburg, 2016)

9. S. G. Stelma, Audit and Fin. Analysis, 2, 422-428 (2010)

10. V. V. Buzyrev, Issues of Economy and Management, 7(47) (2015)

11. O. S. Gaydaychuk, Scientific Notes of the TOGU, 4, 268-271 (2013)

12. T. I. Morozova, Econom., Stat. and Inform. Bulletin of the UMO, 1, 138-141 (2012)

13. T. V. Shcherbakova, Innovation economy: information, analysis, forecasts, 5-6, 98 (2011)

14. V. M. Balkin, Proceedings of the Samara State University of Architecture and Civil Engineering, 1, 74-76 (2012) 
15. V. L. Yasnitsky, Fundamental Research, 10(3), 650-653 (2015)

16. C. Zhuge, C. Shao, J. Gao, C. Dong, H. Zhang, Comp., Environment and Urban Systems, 57, 93-105 (2016)

17. I. García-Magariño, R. Lacuestaa, Journal of Computational Science, 21, 60-76 (2017)

18. R. Borst, Journal of Property Tax Assessment \& Administration, 1, 5-15 (1995)

19. H. Augustyniak, K. Olszewski, J. Waszczuk, J. Łaszek, Uniwersytet Warszawski Wydział Nauk Ekonomicznych, 35, 5-23 (2013)

20. C. Brooks, Introductory econometrics for finance (Cambridge University Press, Cambridge, 2012)

21. V. Zujoa, D. Car-Pusicb, V. Zileska-Pancovskac, Social and Behavioral Sciences, 119, 672-681 (2014)

22. P. Gong, D. Zou, J. Wang, Physica A: Statist. Mech. and its Appl., 500, 177-188 (2018)

23. Krasnoyarsk City Council, Decision of the Krasnoyarsk City Council on the zones of town-planning value (Krasnoyarsk, 1999) 